\title{
THE EFFECT OF ENTREPRENEURIAL ORIENTATION ON MELINJO PROCESSING INDUSTRIES IN BATANG REGENCY
}

\author{
Intan Adhitya Rosmasari ${ }^{* 1}$, Siti Jahroh*), and Budi Purwanto**) \\ *) School of Business, IPB University \\ Jl.Raya Pajajaran,Bogor 16151 \\ **) Department of Management, Faculty of Economics and Management, IPB University \\ Jl. Agatis, Campus IPB Dramaga, Bogor 16680
}

\begin{abstract}
Micro, small and medium enterprises play an important role in improving the people's economy. The contribution of small enterprises can increase state income, absorb labor, improve welfare evenly, and stimulate people's economy by leading to the entrepreneurial orientation to support better business performance. The purposes of the study were to find out the effect of entrepreneurial orientation on business performance and the effect of entrepreneurial characteristic on entrepreneurial orientation and performance. The respondents were taken from 60 independent entrepreneurs and KWT Tani rejo of the melinjo chips processing industry in Batang Regency. The data were analyzed using Partial Least square (PLS) approach. The results showed that entrepreneurial characteristic influenced entrepreneurial orientation and business performance. In addition, entrepreneurial orientation had a positive effect on the performance of melinjo chips processing business. Entrepreneurs who implement entrepreneurial orientation from innovativeness, proactiveness, competitive aggressiveness, risk-taking and power of autonomy side will have a good impact on their business performance.
\end{abstract}

Keywords: MSMEs, entrepreneurial characteristic, entrepreneurial orientation, business performance, PLS

Abstrak: Usaha mikro, kecil dan menengah berperan penting dalam peningkatan ekonomi masyarakat. Kontribusi usaha kecil dapat meningkatkan pendapatan negara, banyak menyerap tenaga kerja, pemerataan kesejahteraan, dan penggerak ekonomi kerakyatan dengan mengarah pada orientasi wirausaha untuk menunjang kinerja usaha yang lebih baik. Tujuan penelitian mengetahui pengaruh orientasi kewirausahaan terhadap kinerja usaha serta pengaruh karakter wirausaha terhadap orientasi kewirausahaan dan kinerja. Responden diambil 60 pengusaha mandiri dan KWT Tani rejo pada Industripengolahan emping melinjo di Kabupaten Batang. Analisis dilakukan menggunakan mendekatan Partial Least square (PLS). Hasil menunjukkan bahwa karakter wirausaha berpengaruh terhadap orientasi kewirausahaan dan kinerja usaha. Selain itu orientasi kewirausahaan berpengaruh positif terhadap kinerja usaha pengolahan emping melinjo. Pengusaha yang menerapkan orientasi kewirausahaan dari sisi inovatif, proaktif, agresif kompetitif, berani berisiko dan kekuatan otonomi akan berdampak baik pada kinerja usahanya.

Kata kunci: UMKM, karakter wirausaha, orientasi kewirausahaan, kinerja usaha, $P L S$

\footnotetext{
${ }^{1}$ Corresponding author:

Email: intan.rosmasari@gmail.com
} 


\section{INTRODUCTION}

Women entrepreneurs in Indonesia are becoming more creative to develop their businesses. It can be seen from the data from the International Finance Corporation (IFC) in 2016 showing that woman owning micro, small and medium enterprises (MSMEs) contributed $9.1 \%$ of GDP (Gross Domestic Product). In general, MSMEs contribute $99 \%$ of all existing businesses, employing $89 \%$ of the private sector workforce and contributing $57 \%$ in GDP. It encourages the increase of income and reduction of poverty. This potential is used by the Indonesian government to identify the MSMEs sector as a key factors to increase economic growth, create employment and reduce poverty. Entrepreneurship is an important issue in economic development (Haliq, 2017).

According to Tamara (2013), economic development is a process to improve and develop the business climate, for micro, small or medium enterprises, which is caused by an activity or initiative from the community which has sustainable impacts beyond the nationhood and the statehood to improve the economy and welfare of the community. Data from the Ministry of Cooperatives and MSME show that the number of micro, small and medium enterprises has reached 59, 267,759 units. The details of developments in 2015 included 58,521,987 units of micro enterprises, 681,522 units of small enterprises and 59,263 units of medium enterprises.

The efforts in developing the people's economy need to be geared to encourage structural change by strengthening the position and role of the people's economy in the national economy. It is an approach in people's economy as SMEs development (Rizani, 2015). Micro, Small and Medium Enterprises (MSMEs) are a stimulus of regional potential development based on people's economy (Irawan, 2015). Small enterprises have a role in the economic development and movement of a country (Urata, 2000) like in Indonesia. The contribution of small enterprises can increase state income, absorb labor, improve welfare evenly, and stimulate people's economy.

A business which adopts entrepreneurial orientation will tend to perform better than a business which does not adopt entrepreneurial orientation (Raunch and Wiklund, 2009). Entrepreneurial orientation refers to processes, practices and decision-making thatencourage new input and have five aspects of entrepreneurship, namely, innovativeness, proactiveness, risk-taking, autonomy and competitive aggressiveness (Lumpkin and Dess, 1996). In measuring the entrepreneurial orientation, the agents of MSMEs can measure the extent to which business improvements can be carried out. Those measurements can be conducted in all areas of MSMEs, one of which is MSME in the field of processed food of melinjo chips in Batang Regency, Central Java Province. Most melinjo chips in Central Java are produced in Batang Regency. In Table 1, the data show that the Melinjo chips industry becomes a center compared to other businesses in Batang Regency.

Table 1. MSMEs in Batang Regency in 2017

\begin{tabular}{lc}
\hline MSMEs types & Business unit \\
\hline Melinjo chips & 6,250 \\
Red bricks & 362 \\
Pindang fish & 225 \\
Cassava chips & 215 \\
Honey & 198 \\
\hline
\end{tabular}

Source: Industry and Trade Office of Batang Regency in 2017

Most of MSMEs in Batang Regency are carried out on a small and independent scale; however, there are some MSMEs that work in groups. The existence of MSMEs formed by groups is seen as a way carried out by the regional government to improve the economy of their communities. Besides, the importance of MSMEs established by groups is that there are sense of togetherness and mutual cooperation within members to jointly grow their group business to become more profitable and beneficial for a lot of people and the environment. The scope of this research is on selfemployment in the sector of micro, small and mediumsized industrial processing chips gnetum residing in Batang, Central Java.

To support their business performance, the entrepreneurs can implement entrepreneurially oriented strategies towards their business. It is because businesses that show changes in entrepreneurial orientation will improve their business performance and business success. In real business practice, this statement suggests that businesses which apply entrepreneurial orientation will perform better (Madsen, 2005). Entrepreneurial orientation becomes important in enhancing the commercialization of University Research Malaysia products through sales of products of research and innovation (Latif, 2016). Besides, research conducted by Mason et al. (2015) on 
300 SMES in the province of Udine Italy and Southern Austria Crankcase area shows the positive effect of entrepreneurial orientation on financial performance, which focuses on innovative attitudes, risk taking, autonomy and aggressive competition. Relationship orientation and performance of businesses in the internal social exchange perspective have a strong relationship when approaching organizational procedural justice social, organizational commitment, and conducive confidence (Clercq et al. 2010).

It is important that the entrepreneurial orientation needs to be considered in order to support the business performance of the melinjo chips processing. Moreover, with the government's support, the MSMEs can be a regional economic booster sector. In this study, it is highly possible to find out the purposes of the research: Analyzing the effect of entrepreneurial orientation on the business performance of melinjo chips processing in Batang Regency; Analyzing the influence of entrepreneurial characteristic on entrepreneurial orientation and business performance of melinjo chips processing in Batang Regency.

\section{METHODS}

This study was conducted in Limpung District, Batang Regency, the largest production unit of melinjo chips. Besides, there are a large number of melinjo plantation areas in Batang Regency. This enables the entrepreneurs to easily obtain raw materials for making chips. Thus this study was very appropriate to be conducted in Limpung District, Batang Regency.

The data were collected using questionnaires and interviews with melinjo chips entrepreneurs. The study was conducted in May 2018. In addition, the data were also taken through related offices such as the Industry and Trade Office, Cooperatives and MSMEs Office, Food and Agriculture Office and other relevant offices. The research respondents were from the thirty KWT Tani Rejo members, and they were determined through census. This study used census because in that area there was only one KWT with thirty members and its characteristics were homogeneous. The respondents outside KWT reached 30 people consisting of entrepreneurs who processed melinjo chips independently in Batang Regency.
This research required a research framework used to facilitate the research to run in accordance with the framework that would be used as a reference. Entrepreneurial characteristic is one factor that may affect the entrepreneurial orientation of a business, and this consists of gender, education, business scale, and age. This characteristic will also influence an entrepreneur to act in his/her business process. Entrepreneurial orientation may be used as an alternative for businessmen to conceptualize their entrepreneurship. Moreover, dimensions of entrepreneurial orientation include innovativeness, proactiveness, risk-taking, autonomy and competitive aggressiveness. Based on these characters, there is a question i.e. which characteristics can determine the influence of entrepreneurial orientation. Orientation may also affect the business performance of melinjo chips.

The model in this study used latent variable of entrepreneurial characteristic with 4 indicators, namely, gender, education, business scale, and age. The latent variable of entrepreneurial orientation consisted of 5 indicators namely innovativeness, proactiveness, risktaking, autonomy and competitive aggressiveness. Then, the latent variable of business performance was measured based on 3 indicators: increased income, production and market expansion. In line with the purpose of this study, entrepreneurial orientation which gave effects on the business performance of the melinjo chips processing industry would be analyzed. The condition of MSMEs of melinjo chips in Batang Regency showed the influence of entrepreneurial orientation on the business performance of the entrepreneurs. The research framework of this study in Figure 1.

The variables of entrepreneur characters included the indicators of gender (KW1), education (KW2), business scale (KW3), and age (KW4). The variables of entrepreneurial orientation were explained by competitive aggressive (EO1), innovative (EO2), autonomous (EO3), proactive (EO4) and risk taking (EO5) indicators. The business performance variable had indicators of production level (KU1), income level (KU2) and market reach (KU3).

The concept of this study was the characteristic which determined a good business seen from the gender, educational background, age and business scale that would influence the entrepreneurial orientation. 
Entrepreneurial orientation consisted of innovativeness, proactiveness, autonomy, competitive aggressiveness and risk-taking that would affect business performance in terms of production, income, and market reach.

The hypothesis is the presumption about the relation among variables presented in the form of questions and assumptions that need to be examined using data. Based on the introduction, literature review, and research framework in this study, the following conclusions can be made as follows:

H1 : Entrepreneurial orientation has an effect toward the business performance of the melinjo chips production

H2 : Entrepreneurial characteristic has an effect toward the business performance of the melinjo chips production

H3 : Entrepreneurial characteristic has an effect toward the entrepreneurial orientation of the melinjo chips

Accepting the hypothesis if all the variables show impacts, but rejecting the hypothesis if there is no impact at all from the hypothesis proposed in this study. To test the hypothesis, the data were analyzed using Partial Least Square Structural Equation Modeling (PLS-SEM) approach. The indicators of entrepreneurial characteristic weregender, education, business scale, and age (Delmar, 1996). There were 5 variables that became the indicators of entrepreneurial orientation, namely, innovativeness, proactiveness, risk taking, competitive aggressiveness and autonomy. Innovativeness plays an important role in entrepreneurship. It is regarding to whether entrepreneurs worked in a culture that supports new ideas, experimentation, new solution to the problems, and also creative process from entrepreneurs would determine the strength of innovativeness dimension from entrepreneurial orientation (Lee and Peterson, 2000). Proactiveness is a perspective in looking for the chances or opportunities to compete and act while anticipating to the environmental changes in the future (Covin and Slevin, 1991). Risk-taking in entrepreneurship is the extent to which a company is willing to make high risk commitments (Covin and Slevin, 1991). Competitive aggressiveness dimension refers to pro-obstacle culture such as a culture and entrepreneurial potential encouragement (Lee and Peterson, 2000). Autonomy in business means that the entrepreneurs have to work in a culture that encourages them to be independent, maintain personal control and look for opportunities in the absence of social constrains (Lee and Peterson, 2000), whereas indicators of business performance consist of the level of production, income and market reach.

\section{RESULTS}

Batang Regency is located in 6o 51 '46" to 7011 ' $47^{\prime \prime}$ South Latitude between 109 40'19" and $110^{\circ} 03^{\prime} 06^{\prime \prime}$ East Longitude in the north coast of Central Java and it is on the main line connecting Jakarta - Surabaya. Batang Regency has a total area of 78.864,16 Ha. The regency is bordered by the Java Sea in the north, Kendal Regency in the east, Wonosobo and Banjarnegara Regency in the south and Pekalongan Regency and City in the west. There are 15 districts in Batang Regency, one of which is Limpung District, the center of the Melinjo chips processing industry. Based on the data from Industry office, trade and cooperative office and SMEs office in Batang Regency, as many as 6,250 units or $30 \%$ of business unit of the Melinjo chips is located in Limpung District.

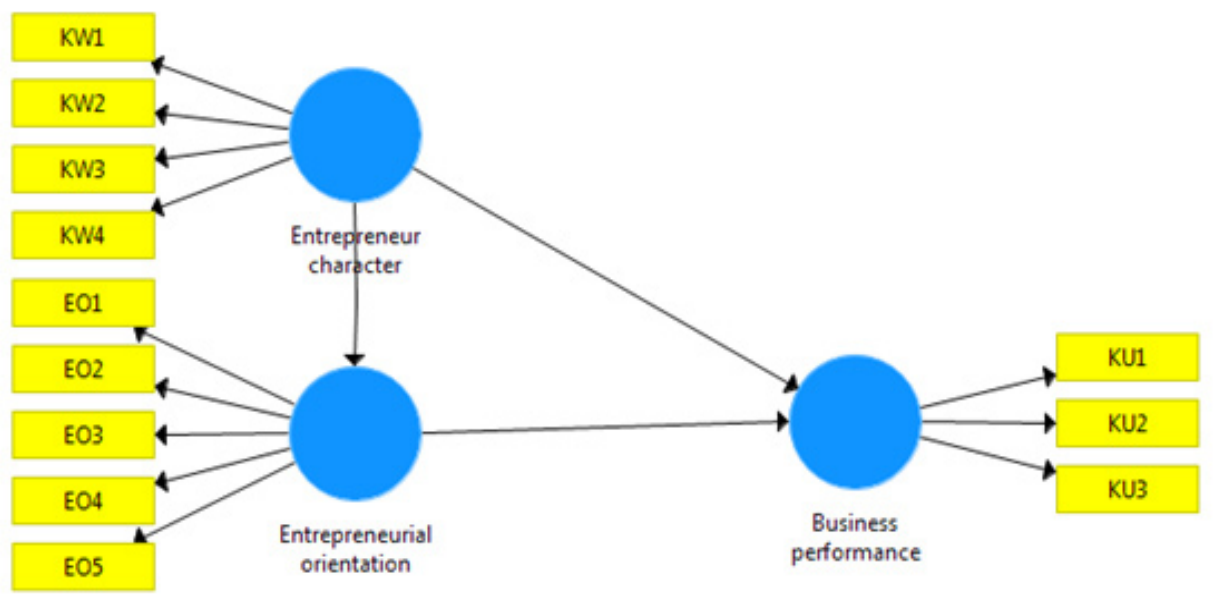

Figure 1. Research framework 
The respondents in this study were entrepreneurs in the melinjo chips industry in Limpung District, Batang Regency. They were divided into two: the entrepreneurs who joined the KWT Tani Rejo and the independent melinjo chip entrepreneurs. KWT Tani Rejo was established on June, 21st 1995. It was established by the Agriculture office of Batang Regency with Istianah as the leader. KWT in Ngaliyan village is quite potential and has a historical value. This is because Ngaliyan Village is a pioneer of the melinjo chips business. KWT is also the place for empowering people of Ngalian village which is organized and based on prosperous economic activities. In 1995-2018, the organization experienced the ups and down in its activity and productivity. There are 30 members of KWT, most of whom work as melinjo chips maker and housewives, but this did not discourage them from moving forward. The target market of Melinjo chips production has reached the export level. In 2013, the KWT Tani Rejo became the largest melinjo chips producer in Indonesia and was recognized by the MURI Record.

Independent entrepreneurs of melinjo chips in Batang Regency have built their own business independently or continue their family business. These entrepreneurs have employees to assist the processing of melinjo chips, but all controls in entrepreneurship are fully taken by the owner. Melinjo chips entrepreneurs are from Chinese and Javanese ethnics. In their entrepreneurial journey they always compete in prices and markets. Besides, the independent entrepreneurs usually run their business from generation to generation, and some entrepreneurs run their business by self-taught. The potential of melinjo chips in Batang Regency is very large, and their target markets are Java, Kalimantan and overseas.

\section{Test Result of SEM-PLS Analysis}

The Analysis in this study used Structural Equation Modelling (SEM) with Partial Least Squares (PLS) approach using smartPLS 3.0 software. The result of PLS model in Figure 2.

\section{Outer model evaluation}

The measurement evaluation result on initial model for convergent validity was seen from the indicator with an assessment of factor loading score. The indicator of this study had minimum factor loading score of 0.3 (Latan and Ghozali, 2012). Hence, there were no scores below the minimum limit in this study, so this calculation provided a valid score based on the evaluation criteria of PLS model measurement. The variable in the study of melinjo chips industry included the latent variable of Entrepreneurial characteristic reflected by gender, education, business scale, and age indicators. The latent variables of entrepreneurial orientation were reflected by competitive aggressiveness, innovativeness, autonomy, proactiveness and risk-taking indicators. Meanwhile, the latent variables of business performance were reflected by production level, income level and market expansion indicators.

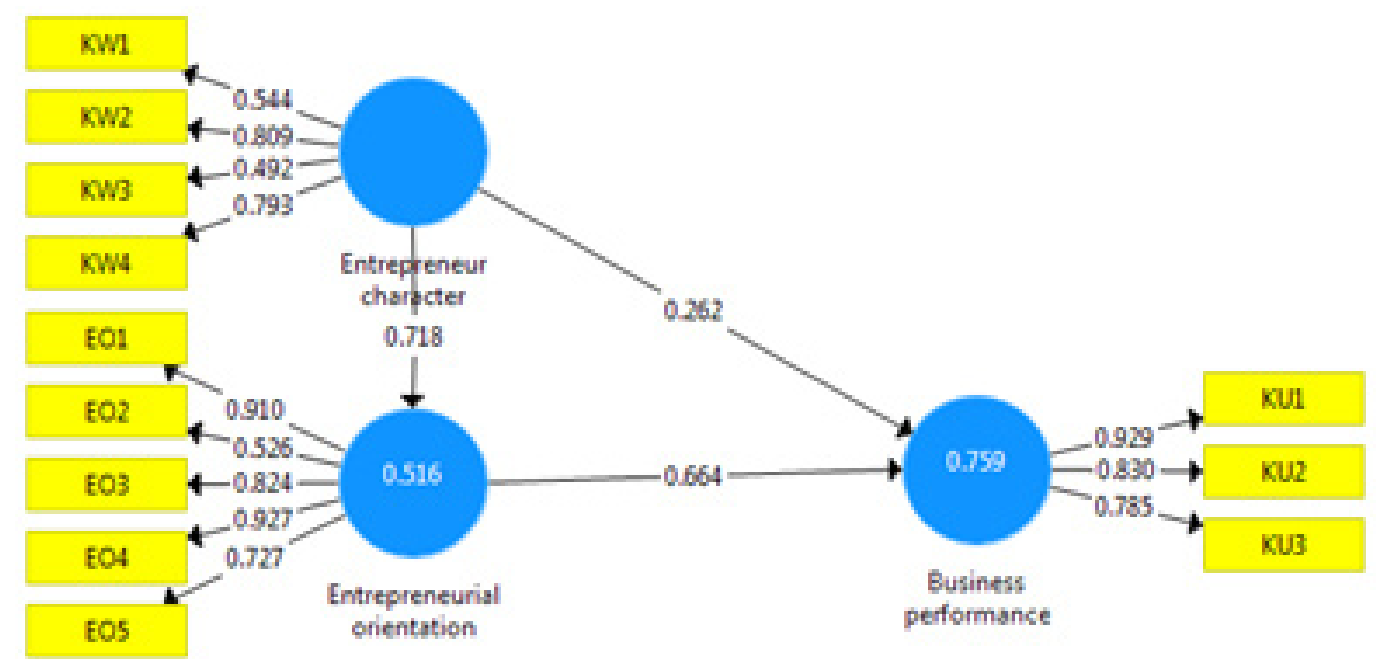

Figure 2. The result of PLS model 
Discriminant validity was applied to see the relation with the principle that different constructions should not be highly correlated. To see the validity of cross loading score of each latent variable, the target core was $>0.50$ which meant that $50 \%$ or more of this score had more variants than the indicators that could be explained. This study showed that cross loading score was above the standard score. This indicated that this model had no problems. Moreover, from AVE score, if the score was $>0.7$ or its score was $>0.4$ and obtained AVE score of $>0.5$, it could be said that i-indicator was valid. This study showed that AVE score was $>0.4$. In conclusion the validity and reliability test had passed the standard (Latan and Ghozali, 2012).

Inner model evaluation

Inner model evaluation was used to see the relation between latent constructs by looking at the estimation result of path coefficient parameter and significance level (Latan and Ghozali, 2012). First, observing the R-square value (R2). R2 value had exceeded $50 \%$, which meant the model was in accordance with the standard, and the rest was not explained in this study. Entrepreneurial characteristic variable had several indicators, namely, gender (KW1), education (KW2), business scale (KW3), and age (KW4) indicators (Delmar, 1996). Latent variable of entrepreneurial orientation was explained by competitive aggresiveness (EO1), innovativeness (EO2), autonomy (EO3), proactiveness (EO4) and risktaking (EO5) indicators (Lumpkin and Dess, 1996). Business performance variable consisted of production level (KU1), income level (KU2) and market reach (KU3) indicators (Delmar, 1996).

The highest score in Entrepreneurial characteristic was in education i.e. 0.809. In this case, it indicates that education formed the most latent variable of Entrepreneurial characteristic. This indicator showed that the higher of the education of entrepreneurs who run business in melinjo chips industry, the more they can apply his knowledge in solving the entrepreneurship problem. Beside that, with higher education, they can learn that the business cycle of melinjo chips is not always round but also steep and fluctuative as it depends on the condition of raw materials and market demand. The higher the education of melinjo chips entrepreneurs, the wider the target market and partner range during the process, and they become calmer in facing problems. Education taught them to be calmer in every situations. However, a person's entrepreneurial orientation could be different according to his behavior (Dirlanudin, 2010).

The highest score of entrepreneurial orientation was in proactiveness indicator (EO4) i.e. 0.927, while the lowest score was in innovativeness indicator (EO2) of 0.526. It could be explained that the proactiveness attitude encouraged entrepreneurs to move forward and tried to compete with other entrepreneurs. The entrepreneurs always tried to sell melinjo chips with the best quality, so the entrepreneurs always managed to improve their melinjo chips quality. The entrepreneurs' activeness to improve melinjo chips quality started from raw material in which they chose good quality of melinjo raw materials, such as ripen, hard, not very soft and not defective seeds. Usually melinjo seeds which are defective due to insects cause black or brown mark on the melinjo chips. Besides, entrepreneurs also actively develop their products and look for new markets for melinjo chips. In addition, the prices set by the market become a reference for entrepreneurs to determine the prices to compete with the other competitors.

The lowest score was in innovativeness indicator i.e. 0.526 . It showed that the melinjo chips industry lacked of breakthroughs related to product and technology. It is because entrepreneurs were reluctant to switch from manual processing to the latest technology. KWT Tani Rejo once received donation in the form of technology for melinjo chips processing, but the products produced did not make them satisfied. The chips turned out to be very soft, easy to get moldy, and not as crunchy as using the manual process. Besides, many entrepreneurs disagreed with other melinjo production form except for melinjo chips. It is because of the lacks of market interest, and the process was inefficient.

Business performance can be considered to be good if there is an improvement in production, income and market expansion, as seen in Figure 2 which showed that the increase in production had a high score of 0.929 . This could be interpreted that the most influential indicator of the business performance variable was the increase of melinjo chips production. This increase was the result of entrepreneurial orientation and policy influence. Production becomes a determining factor of a business. The increase in production would affect the enthusiasm of entrepreneurs to actively run their business activities. Besides, the increase in income will also create opportunities for the development of other businesses (Rifa'i, 2010). 


\section{The Effects of Entrepreneurial Orientation on Business Performance}

The result of the study indicated that the entrepreneurial orientation of melinjo chips processing had a positive and significant effect on business performance. Business performance was strongly influenced by entrepreneurial orientation (Dilmar, 1996). MSMEs implementing entrepreneurial orientation showed good result on their business (Rauch and Wiklund, 2009; Lumpkin and Dess, 1996; Miller, 1983). This is suitable with the facts in the field that entrepreneurs who implements entrepreneurial orientation obtain better results both from production and market networks which have an impact on the increase of their income (Lumpkin and Dess, 2001; Raunch and Wiklund, 2005). However, orientation had a negative effect on the research (Ho, 2017). Entrepreneurial orientation is an important aspect in running business (Lumpkin \& Dess 1996), because it helps them to achieve the goals of their business. There are five indicators of entrepreneurial orientation, namely: innovativeness, proactiveness, risk-taking, autonomy and competitive agressiveness (Lumpkin and Dess, 1996). Innovativeness in this study was seen from the attempt to create something new (Damanpour, 1991), such as new product innovations (Johne, 1999), variety of flavors, use of new technology and innovative marketing concept to increase the market (Lukas and Ferrell, 2000). Based on the facts in the field, melinjo chips industries have not dared to change their old pattern. For example, they are reluctant to change the shape of melinjo chips that is flat-round. Besides, the presence of the new technology from the government is expected to ease the work in producing melinjo chips, but they are not as good as manually produced chips in terms of quality. The chips become very soft and rotten quickly, fragile, and inefficient. It was what made the innovativeness indicator in this study the lowest among the five indicators. In line with Covin and Miles (1999), innovation is not strong enough to strengthen a business, if it is not accompanied by the position and business competitors.

Proactiveness indicator of melinjo chips industry was indicated by the activeness criterion in looking for information about market and price condition, and the entrepreneurs should actively look for the opportunities to surpass the competitors. In this study, the score of proactive indicator had the highest score. In reality, the proactiveness of melinjo chips entrepreneurs can be seen from the entrepreneurs who are very active in updating information about selling prices of melinjo chips, because melinjo chips prices are very fluctuating, so they cannot be predicted. This is because the one who determines the prices of raw melinjo chips is one of the melinjo chips entrepreneurs who dominates raw materials and melinjo chips products in Batang Regency. Besides, the changing price of melinjo chips is also based on the market demand and availability of raw materials (Istiyanti and Kamardiani, 2017). Therefore, entrepreneurs are very active in finding price information in order to compete with the competitors. Prices from one entrepreneur to other entrepreneurs are very different; moreover, if the entrepreneurs cannot get the raw material independently, their melinjo chips will be more expensive than those of the other entrepreneurs. Furthermore, they should actively look for a loyal market and buy melinjo chips from other entrepreneurs. The way of each entrepreneur looks for their markets is different. There are some entrepreneurs who are more comfortable selling their melinjo chips to the big collectors in the district. There are also entrepreneurs who prefer selling their melinjo chips out of town to loyal customers who order melinjo chips every month, week and even every three days. However, there are also entrepreneurs who sell their melinjo products to the traditional markets out of the town by delivering these products using pickups or trucks. This is in line with the study by Lumpkin dan Dess (2001) which stated that proactive businessmen can target their market and take advantage on the existing opportunities to compete. Besides, proactiveness side of entrepreneurs is carried out by competing to improve the quality of their melinjo products than their competitor products. It can also be done by developing products by adding business partners and increasing the production capacity of melinjo chips; therefore, this proactive process can improve the economy of producers (Kurniawan, 2013) The third indicator is risk-taking. Daring to take risks means the entrepreneurs are willing to take risky decisions, such as when they experience a loss on their business or dare to increase business capital by using credits loan. Entrepreneurs prefer to calculate the risk on the processing of melinjo chips to avoid the risk that might occur. Therefore, they always look for ways to avoid failures such as handling the availability of raw materials and working hard to reduce the risk that might happen. 
The next indicator is autonomy in entrepreneurial orientation of melinjo chips industry. Its indication stated that the processing must be carried out according to its sequence. New technology is implemented slowly; moreover, the decision making is done by discussions, and the leader is the one who makes a decision. The reality in the field of entrepreneurship indicates that the entrepreneurs of melinjo chips stated that the process of melinjo chips has been passed down for generation to generation from the predecessors in Ngaliyan Village. The pioneers of melinjo chips production are from Ngaliyan Village, where KWT Tani Rejo is located. The process is still done manually, and the only difference is the material. In the past, melinjo chips were made using stone or any strong materials used as the base, and the container sheet was made of leaves or other materials. Currently, the process of making melinjo chips is more hygienic, like using clean stone base, and it is usually flat and square-shaped, and the tool to flatten the melinjo fruits was a stone shaped like a hammer that weighs up to $5 \mathrm{~kg}$. After that, melinjo chips were dried under the sun heat using a clean plastic container sheet. It indicates that the process of melinjo chips production is still carried out manually by maximizing the existing resources. Besides autonomy on the leadership side, the entrepreneurs tend to appoint themselves as the highest decision makers in the entrepreneurship. The processing of melinjo chips is still manual and the management system is still simple (Aman et al. 2013). However, there are also several entrepreneurs who conduct discussions in every decision making for the sustainability of the melinjo chips business.

The fifth indicator is competitive aggressiveness in the entrepreneurial orientation of the melinjo chips industry. The criterion of competitive aggressiveness is the willingness to defeat competitors, thus trying to expand the market network for the distribution of melinjo chips products with various sacrifices. In reality, there are entrepreneurs who sacrifice their other business income to expand their market for melinjo chips by setting prices below the competitors' prices. In addition, processing of melinjo chips should be conducted effectively and efficiently to reduce production costs, but they still prioritize the quality to show their competitiveness with competitors.

\section{The Effects of Entrepreneurial Characteristic on Business Performance}

The coefficient value showed 0.262 with the $t$-value of 2.455 which had exceeded 1.96 from the $t$ table, while the score of p-value was still below 0.05. Entrepreneurial characteristic had an influence on the entrepreneurial orientation with a positive path of coefficient value. It showed that there was acontinuity. Entrepreneurial characters had significant effects on entrepreneurial orientation. In this case, the Entrepreneurial characteristic of female entrepreneurs is easier to apply on the entrepreneurial orientation compared to that of the male entrepreneurs. The production of business is increasing because of the woman's perseverance in business (Groot et al. 2017). This is because the way women and men think are different in running the businesses. The personal entrepreneurial characteristics of women in the shrimp cracker business in Jambi Province are the most important variables in influencing business performance of women entrepreneurs (Martauli, 2016). In addition, the length of years in business in entrepreneurship indicates an influence on entrepreneurial orientation. The longer the businessmen runs their melinjo chips business, the more prominent their proactive attitude will be. Entrepreneurs will be more familiar how to take the opportunity to compete with other entrepreneurs. This also causes the risk taking to be minimized in entrepreneurship. The more mature and experienced an entrepreneur in the melinjo chips industry, the more familiar they become with best quality. The best quality of the chips will increase the price of the product itself. The impact is the businessmen's income increased. The results of the study by Elvin (2016) on female entrepreneurs of shrimp cracker production in Jambi Province showed that training, business experience, education, and family background had positive effects on entrepreneurial behavior (motivation, innovation and risk taking).

\section{The Effect of Entrepreneurial Characteristic on Entrepreneurial Orientation}

A good entrepreneurial orientation in MSMEs-based business is strongly influenced by entrepreneurial character. The result of the study indicated that the Entrepreneurial characteristic had positive effects on entrepreneurial orientation. Entrepreneurial characteristic variables had positive and significant effects on entrepreneurial orientation with t-count of 
13.605, indicating that it was higher than t-table value of 1.92. It is in line with the reality in the field which shows that education has an influence on the processing of melinjo chips. It is proved that the businesses that have been managed by entrepreneurs' parents exist well and are well managed. Besides, the quality is also better than the startup business and small scale business. It is also because the entrepreneurs who have higher levels of education are better in managing their business optimally and in utilizing the existing melinjo resources.

\section{Managerial Implications}

Businesses that focus more on entrepreneurial orientation will perform well through a proactive attitude. Being proactive means moving forward looking for information and competing to be the pioneer in the business of gnetum chips. Doing the latest innovations on chips will encourage gnetum performance effort further. Education becomes an important key in improving business chips with a sense of curiosity, gnetum gnemon is high to keep learning and their processes. Having education and being proactive are efforts to improve the performance of the venture chips gnetum. It is expected that more businessmen to have a high level of education so that they will think proactively.

\section{CONCLUSIONS AND RECOMMENDATIONS}

\section{Conclusions}

Based on the model results, it can be concluded that variables of Entrepreneurial characteristic have positive and significant effects on entrepreneurial orientation. Beside that an entrepreneurial characteristic and entrepreneurial orientation also have positive and significant effects on business performance. It shows that the Entrepreneurial characteristic has an influence on business performance both directly and indirectly; likewise, the entrepreneurial orientation plays an important role in improving the business performance of the melinjo chips processing industry in Batang Regency, because the entrepreneurial orientation influences the business performance of the processing of melinjo chips.

\section{Recommendations}

To improve entrepreneurial performance, it is necessary to increase proactive attitudes. Proactive attitudes supported by educational levels will have an impact on business performance. In addition, there are several things that can be done to encourage proactive attitudes, such as training and internships program in the same field and other related activities which can increase knowledge. Research on the role of entrepreneurial orientations in management groups needs to be conducted in the following research.

\section{REFERENCES}

Aman Y, Ardian A, Purwanti, ES, Bambang S. 2013. IbM Kelompok Industri Kecil Pengrajin Emping Mlinjo di Beji Pajangan Kabupaten Bantul Daerah Istimewa Yogyakarta. Yogyakarta: IBM.

Clercq DD, Dimov D, Thongpapanl N. 2010. The moderating impact of internal social exchange processes on the entrepreneurial orientation-performance relationship. Journal of Business Venturing 25(1): 87-103. https://doi. org/10.1016/j.jbusvent.2009.01.004.

Covin JG, Miles MP. 1999. Coorporate entrepreneurship dan the pursuit ofcompetitive advantage. Entrepreneurship Theory Dan Practice 23(3): 47-63. https://doi. org/10.1177/104225879902300304.

Covin J, Slevin D. 1991. A conceptual model of entrepreneurship as firm behavior. Entrepreneurship Theory Dan Practice 16: 7-25. https://doi.org/10.1177/104225879101600102.

Damanpour F. 1991. Organizational innovation: a meta-analysis of effect of determinants dan moderators. Academy of Management 34(3): 555-559. https://doi.org/10.5465/256406.

Delmar F. 1996. Entrepreneurial behavior dan business performance : A study of the impact of indivodual diferences dan environmental characteristics on business growth dan efficiency [disertation]. Sweden: Stockholm School of Economic.

Dirlanudin. 2010. Perilaku wirausaha dan keberdayaan pengusaha kecil industri agro: kasus di Kabupaten Serang Provinsi Banten [disertation]. Bogor: Institut Pertanian Bogor. 
Groot JD, Mohlakoana N, Knox A, Bressers H. 2017. Fuelling womens empowerment? an exploration of the linkages between gender, entrepreneurship dan access to energy in the informal food sector. Energy Research and Social Science 28: 86-97. https://doi.org/10.1016/j.erss.2017.04.004.

Haliq I. 2017. Pengaruh orientasi kewirausahaan terhadap kinerja usaha peternakan ayam boiler di Kabupaten Bogor [tesis]. Bogor: Sekolah pascasarjana Institut Pertanian Bogor.

Ho KL, Nguyen CN, Adhikari R, Miles MP, \& Bonney L. 2017. Exploring market orientation, innovation, and financial performance in agricultural value chains In Emerging Economies. Journal of Innovation \& Knowledge 49 : 12-24.

Irawan D. 2015. Potensi usaha koperasi dan usaha keccil menengah di daerah terisolir dan tertinggal. Coopetition 6 (2): 51-62.

Istiyanti E, Kamardiani DR. 2017. Performa supply chain emping melinjo di Kabupaten Bantul Daerah Istimewa Yogyakarta. Journal of Agribusiness and Rural Development Research 3(1): 23-32. https://doi.org/10.18196/agr.3141.

Johne A. 1999. Successful market innovation. European Journal of Innovation Management 2(1): 6-11. https://doi.org/10.1108/14601069910248838.

Latan H, Ghozali I. 2012. Partial Least Square Konsep, Teknik, dan Aplikasi SmartPLS $2.0 \mathrm{~m} 3$ untuk Penelitian Empiris. Semarang: Badan Penerbit Universitas Diponegoro.

Latif NS. 2016. A pilot study of entrepreneurial orientation towards commercialization of university research product. Procedia Economics dan Finance 37: 93-99. https://doi.org/10.1016/ S2212-5671(16)30098-3.

Lee S, Peterson S. 2000. Culture, entrepreneurial orientation dan global compeitiveness. Journal of World Business 35: 401-416. https://doi. org/10.1016/S1090-9516(00)00045-6.

Lukas BA, Ferrell O. 2000. The effect of market orientation on product innovation. Journal of Academy Of Marketing Science 28: 239.
Lumpkin G, Dess G. 1996. Clarifying the entrepreneurial orientation contruct dan linking it to performance. Academy of Management Review 21(1): 135-172. https://doi.org/10.5465/ amr.1996.9602161568.

Lumpkin G, Dess G. 2001. Linking two dimensions of entrepreneurial orientation to firm performance: The moderating role of environment dan industry life cycle. Journal of Business Venturing 16 (5): 429-451. https://doi.org/10.1016/S08839026(00)00048-3.

Madsen EL. 2005. The Significance of Sustained entrepreneurial orientation on performance of firms, a longitudinal analysis. Entrepreneurship dan Regional Development 19: 185-204. https:// doi.org/10.1080/08985620601136812.

Martauli ED. 2016. Faktor-faktor yang berpengaruh terhadap kinerja usaha wanita wirausaha kerupuk udang di Provinsi Jambi. Jurnal AGRARIS 2(2): 119-127. https://doi.org/10.18196/agr.2232.

Miller D. 1983. The Correlates Of Entrepreneurship In Three Types of Firm. Management Science 29(7):770-791.https://doi.org/10.1287/ mnsc.29.7.770.

Rauch A, Wiklund. 2009. Entrepreneur orientation dan business performance:cumulative empirical evidence. Entrepreneurship Theory and Practice 33(3): 761-788. https://doi.org/10.1111/j.15406520.2009.00308.x.

Rifa'i A. 2010. Peran UMKM dalam pembangunan daerah: fakta di Provinsi Lampung. Jurnal Ilmiah Administrasi Publik dan Pembangunan 1(2): 133-143.

Rizani NA. 2015. Kapasitas Usaha Mikro Kecil Dan Menengah Dalam Pengembangan Ekonomi Lokal. Bogor: Laporan Studi Pustaka Institut Pertanian Bogor.

Tamara A. 2013. Pemberdayaan usaha mikro, kecil dan menengah di Kota Manado (ditinjau Berdasarkan Undang-Undang Nomor 20 Tahun 2008). Jurnal Universitas Sam Ratulangi 1(5): 64-79.

Urata S. 2000. Policy Recommendation For SME Promotion In The Republic Of Indonesia. Japan: Japan International Coorporation Agency. 